\title{
Urban Land Grabs in Africa?
}

\author{
GRIET STEEL, FEMKE VAN NOORLOOS and KEI OTSUKI
}

\begin{abstract}
Africa is rapidly urbanizing. New dynamics of investments and mobilities ensure expansive urbanization, transforming the continent's urban land and built environment. These changes also impact future prospects for sustainable living conditions for African urban dwellers. This issue of Built Environment has collected articles that observe these changes, in order to explore whether they are indeed leading to 'urban land grabs', which take place in new forms of commodification and speculation of land and properties. We recognize that the trend of commodification and speculation is likely to intensify, as the new modernization agenda is propagated in the name of pursuing urban sustainability and resilience, corresponding to the New Urban Agenda and Sustainable Development Goals. At the same time, inclusive urban development is also debated in these international agendas, as ordinary citizens increasingly confront livelihood and land-use changes, spatial alteration and social segregation, or physical displacement. In this context, we know little about how African urban dwellers' experiences could be understood and used to envision genuinely sustainable and inclusive urban development. In this editorial, we give an overview of various emerging urban land investments and how they are experienced by urban dwellers. As shown in all the articles of this issue, we argue that the far-reaching impact of increased investments and mobilities, leading to commodification and land speculation as well as the urban dwellers' agency to navigate the impact, deserve more attention in discussions on sustainable and inclusive urban development in Africa.
\end{abstract}

In recent years, African urbanization has re-emerged on both academic and policy agendas. Within the framework of the urban transition and the global urban turn, the question arises: how can African cities provide sustainable living environments for the rapidly increasing urban population? This concern is reflected in a gradual shift from a primarily rural-focused development model towards an urban development paradigm with a renewed dominance of urban policy agendas (Parnell, 2016). Indeed, not only are African national governments investing time and money in the urban realm, but also the international agenda is currently focused on 'making cities and human settlements inclusive, safe resilient and sustainable' as expressed in Sustainable Development Goal number 11 (Sheppard et al., 2015; UN-Habitat, 2016). In order to meet this goal, increased foreign investment in housing, network infrastructure, and economic development are expected to flow into cities in coming years (Zoomers et al., 2017). In addition, as van Noorloos et al. (2018) indicate, the New Urban Agenda and its call for new and 'well planned' urban solutions, further accelerates investments in urbanization globally, investments which could range from the international donor money to private capital. In this context, African cities are promoted as the new frontier for the global capital inflows (Watson, 2013; Myers, 2015; Fält, 2016; van Noorloos and Kloosterboer, 2018). 
Parallel to these debates is the question of whether there is something particular about the African urbanism (Parnell and Pieterse, 2015). Following postcolonial theories, there is a recent call in urban studies to theorize urbanism from the South (Parnell and Robinson, 2012; Robinson and Roy, 2016; Leitner and Sheppard, 2016; Watson, 2009). Scholars argue that African cities should be taken more seriously in their own right and that they should influence more strongly the theory of urbanism, given their many particularities, e.g. the relative importance of urban informality, the decoupling of economic growth and urbanization, the particularities of the periurban fringe and rural-urban connections, and state fragility (Parnell and Pieterse, 2014; Robinson and Roy, 2016). In addition, the African urbanism is highly diverse as the dynamics of each African city and town are different (Potts, 2012).

In these debates on African urbanism, the question of land is generally mentioned in the side-lines. Although discussions on gentrification, displacement, urban renewal and infrastructure development centre on social, physical, and economic change in urban environments, the land question, which is at the very basis of these transformations in the built environment of African cities, is rarely fully explored or taken as a central point of analysis. As Steel et al. suggest: 'discussions over urban land easily conflate with debates over new urban reconfigurations and gentrifications processes, or what is often referred to as the urban transition' (Steel et al., 2017). Even within the new land-based financing models (see Berrisford et al., 2018; Bon, 2015; Blanco et al., 2016), which are promoted by the New Urban Agenda, land governance and land-based transformations are not necessarily at the core of the discussion. However, due to the intensification of global attention on, and capital inflows into, African cities, various international and national, public and private actors are mobilized to claim urban land, which calls for more attention to the issue of the possible 'urban land grabs' (Steel et al., 2017).
In this issue of Built Environment, we aim to address questions such as: how do increased pressure on and competing claims over land shape urbanization processes in Africa? Are the urban land grabs real? Are they just plans or do these plans actually have impact on the ground? If so, how does this work, in particular in the midst of the international call for sustainable and inclusive development? Who is involved in the process and how do different actors claim their rights to a decent urban living and their right to the city? Whose needs, expectations and ambitions are taken into account in current urban land policies and how do they (re)inforce patterns of inclusion and exclusion?

Originally prepared for the African Centre for Cities (ACC) International Urban Conference, which took place in Cape Town in early 2018, the articles in this issue contribute to answering these questions by drawing on recent empirical studies in a variety of African urban contexts. Together, they give an overview of emerging urban land investments and their impacts on urban dwellers who are increasingly confronting livelihood and land-use changes, spatial alteration and social segregation, or physical displacement.

Before introducing the six articles in this issue, we introduce the debate surrounding urban land and African urbanism in order to give a concise review of current debates and provide a framework for the articles.

\section{The Urban Turn in the Land Grab Debate}

Stemming from the global food, energy and financial crises during the later 2000s, the media hype around the 'global land rush' peaked in the early 2010s. Since then, scholars have been constantly debating the impact of large-scale land acquisitions on development processes in the Global South. These discussions shaped the debates on 'land grabs', focus on the role of foreign investors buying or leasing large pieces of land overseas in general, and in the Global South in particular (Cotula et al., 2009; Deininger and Byerlee, 2011; Holmes, 
2014; Wolford et al., 2013; Borras and Franco, 2013; Kaag and Zoomers, 2014; Zoomers, 2010). More precisely, domestic as well as transnational companies, governments and individuals - driven by changing commodity prices - make competing claims over land in order to find new horizons for the production of food and biofuels. Therefore, initially, the debates centred on the rural context, looking into the impacts of agribusinesses, mining, as well as natural resource management and conservation, on smallholders' livelihoods (Zoomers and Otsuki, 2017).

Recently, the fact that the land grabs also take place in a context of rapid urbanization is beginning to be noticed. According to Zoomers at al. (2017, p. 245):

the global land rush ... is partly a consequence of increasing urban demand and the restructuring of value chains... Moreover, cities themselves act as major 'land grabbers', as they expand due to population growth, the spread of middle class lifestyles and suburbanisation, speculation, and new city development.

Scholars have also noted that the close intertwinement between rural and urban land acquisitions makes it important to look at both processes as two sides of the same coin and to further analyse them from an integrated perspective (Zoomers et al., 2017, van Noorloos et al., 2018). And, in both rural and urban contexts, the same concern of inclusive land governance must be shared in order to support the basic rights of vulnerable groups who tend to be most negatively affected by the process. There is always an underlying exclusionary element of land grabbing in different settings (Mbiba, 2017), and it is vital to look at particularities and commonalities.

Nonetheless, Steel et al. (2017) argue that, in the context of urbanization, land acquisitions take a slightly different form than in a rural context. They put emphasis on some crucial differences:

1. In urban cases, there is no unilineal transfer of local control over land towards more powerful outsiders. Urban land acquisitions involve a variety of actors and as a result the role of public policies in allowing or enhancing land-use change cannot be ignored.

2. In terms of scale, urban land grabs might be less immense. Although there are some significant differences across the regions, in general urban land acquisitions take place on a smaller scale and are more fragmented, gradual and dispersed across the city and therefore are less visible (but not necessarily less radical) than in most rural examples.

3. Issues related to land tenure in cities are always directly related to the question of housing and other basic infrastructure and, hence, indirectly to livelihoods.

Discussions on urban land generally conflate with debates over new urban reconfigurations and gentrification processes (see also Shin et al., 2016). However, we argue that it is important to pay attention to a variety of land acquisition patterns and their effects on urban dwellers and their livelihoods in an urban context. As the empirical cases in this issue show, it can be further discussed whether we should label the dynamics of dispossession and repossession of urban land and their consequences as land grabs or not. At least, we hope that thinking about urban land grabs offers an opportunity to analyse further the mixture of driving forces and effects that are taking place in the Global South in general and African cities in particular. This also helps us to find ways to envisage sustainable and inclusive urban development.

\section{African Cities as the New Investment Frontier - and the Frontier of Land Grabs?}

Urban land grabs are arguably taking place most intensely in expanding African cities. Underpinned by the era of 'neo-liberal urbanization' (Sheppard et al., 2015), private investments are increasingly directed towards the African continent, as it is considered to be a new frontier for foreign and domestic invest- 
ments (Bhan, 2014; De Boeck, 2014; CôtéRoy and Moser, 2018; Fält, 2016; Grant, 2015; Murray, 2015a, 2015b; Watson, 2013). Accordingly, more traditional donors shape the public and private partnerships to accelerate the frontier expansion (Shannon, this issue). The frontier is materialized in different ways: (1) an extension of infrastructure networks (Otsuki, this issue); (2) the construction of entirely new cities built up from scratch in the outskirts of existing cities (van Noorloos, Avianto, and Opiyo, this issue; Fält, this issue); (3) in the restructuring of existing city centres.

At the same time, the investments do not only take place in the form of new city and infrastructure development programmes. Smaller-scale land investments are often made by city dwellers themselves (Stacey, this issue), and transnational migrants trigger land commodification, land-use changes and an increase in land prices (Kaag and Steel, this issue). It should be acknowledged that a messy variety of actors are involved, including local rentier classes, returning migrants and remittance senders, and all kinds of local groups seeking opportunities from new investments.

Investments - large and small - could have a wide variety of impacts on urban dwellers in African cities where a majority are often labelled as informal settlers. How to turn the phenomenon of land grabs into more inclusive development has been a pressing question (Otsuki et al., 2017). In particular, even among the critical scholars, investments in cities and their infrastructure are considered to be highly necessary in African cities (Parnell \& Pieterse, 2014; Watson, 2009). Therefore, there is a fine line between ' $\mathrm{grab}^{\prime}$ and 'development' (van Noorloos et al., 2018), and exclusion and inclusion in the African context. In other words, whether the expansion of the investment frontier in African cities automatically leads to dispossession or 'urban land grabs' is debatable.

\section{Experiences of Investments: Article Summaries}

The articles in this issue examine the relationship between grab and development by looking into different types of land investments in the built environment of African cities across the continent: Nairobi (Kenya), Beira and Maputo (Mozambique), Accra (Ghana), Dakar (Senegal), and Khartoum (Sudan). The authors take the investments in master plans, new city development, infrastructure and peri-urban development as a starting point of analysis and discuss how the investments are experienced by urban dwellers and influence their living environment. The discussions point to multiple facets of the recent urban land grab debate and the role of land in African urbanization in general.

First, when we focus on investments in urban land, we notice how little is actually known about the politics of investments. The article by Shannon: 'African urban development in a post-aid era' looks into Dutch international cooperation that builds its publicprivate partnership in Africa on the ideal of a 'retroliberal' approach. It specifically examines increasing justification for the donor to take business-oriented approaches to collaborate with the city government of Beira in Mozambique. It highlights how the new master plan, which was proposed under the banner of increasing urban resilience in the face of flooding, leads to renewed territorial control of the city and aspirations by international donors and foreign businesses. The article calls for more attention to be paid to donor politics, as African urban development is inevitably enmeshed in global geopolitics as much as national and municipal power struggles.

The next two articles critically examine the ways in which new master-planning actually unfolds in African metropolitan cities. First, the article by van Noorloos, Avianto and Opiyo shows what happens to land when a largescale new city building project is announced. It draws on an example of one of the most 
iconic planned new cities in Africa known as Konza Techno City in the peri-urban area of Nairobi in Kenya. While there is currently not much more than a fence that has been put up around the planned city, real life effects are clearly visible. On one hand, land tenure insecurity is experienced by surrounding villages as a buffer zone has been established to prevent 'informality'. On the other hand, people are seeking opportunities or speculating on future profit. The case illustrates that a plan for a new city can trigger various types of dispossession and patterns of inclusion and exclusion. Therefore, it affirms that it is not easy to draw the line between 'grab' and 'development' or to assign clear 'culprits' that cause dispossession for others: spatial differences and temporal changes make for a constantly shifting landscape of actual and potential impacts.

The article by Fält draws our attention to the governance aspect of such a masterplanned new city. Drawing on the case of Appolonia City, which has been built on the outskirts of the Ghanaian capital Accra on an assumption that it would absorb a growing urban population in the greater Accra region, the article asks how a new city built with largely private investments can be governed in an inclusive way. By investigating what happens to the land belonging to traditional chieftaincy and how private firms build and manage the city, the article argues that it is becoming another gated enclave for new middle-upper classes. This is not only because of the profit-seeking involvement of private parties and traditional authorities, but also due to the workings of the state apparatus, which strives to make the new private city governable. Given the trend of private urban planning across Africa, this rethinking of private-public relations through the lens of 'governmentality' will be useful in analysing wider African urban developments.

If we characterize these new masterplanned cities as an embodiment of new investments, the paper that follows: 'You can have it for God' by Stacey moves away from the central idea that urban land access and control are driven by urban policies, planning and foreign investments. The paper shows that the de facto absence of formal regulatory powers in Ghana's biggest informal settlement, Old Fadama in Accra, opens space for more informal and micro-level land-based developments and investments. In the settlement, local people are investing in mosque building by giving away parts of their land and other material resources. The article illustrates how residents of this informal settlement are active agents in attaching meaning to their lived-in place and establishing relations of property and land outside the reach of the government or private investors. It reminds us that the ways in which urban dwellers obtain access and control over urban land, especially in informal settlements with little state and formal business presence, are profoundly socially as well as morally embedded, and they create local rights of citizenship together with informal relations of property.

The implications of these informal land deals for urban transformation are further analysed in the article by Kaag and Steel. The article focuses on the roles played by transnational migrants who are increasingly targeted as buyers of land in their home cities. Drawing on cases in the peri-urban fringes of Khartoum, Sudan and Dakar, Senegal, the article shows how transnational migrants or the African diaspora more specifically make claims to urban land in particular ways, generating new processes of speculation, rise of land values, and socio-spatial inclusion and exclusion. Addressing whether these transnational migrants can be considered as contributing to urban 'land grabs' or not, the article argues that these often-overlooked actors that drive 'land rush' should at least be part of the analysis. It is not only mega-projects and official business investments that bring about urban transformation. Rather, individuals that form political and economic networks perhaps have larger lasting impacts on urban 
land, and they can exclude others that do not have connections to these networks.

Lastly, the paper by Otsuki: 'Who is in "the public"?' explores the direct consequences of various investments that lead to exclusion or inclusion of vulnerable people by examining the relationships between physical infrastructure, displacement and resettlement. It pays particular attention to the notions of 'development' and 'the public'. Infrastructure as 'public works' often justifies the displacement of people for the sake of the wider population's 'development', and we call this incident a typical case of land grab. However, infrastructure can benefit displaced people if it includes them in the 'public' that participates in their own 'development', especially in the form of ensuring a sound resettlement experience. By discussing how this reconstitution of the public can be envisioned and practised, the article examines experiences of development-induced displacement and resettlement in Mozambique. It concludes that it is important to clarify conceptually what 'development' actually means to whom, and that more attention should be paid to the everyday practices of the displaced people to rebuild or obtain their infrastructure.

\section{Moving Forward: the African Urban Land Question}

The variety of experiences revealed in this issue calls for more scholarly attention to the transformations of African urban spaces and what these changes mean for more vulnerable groups and their 'development'. As new investments and master plans continually emerge, it is vital to share our observations and analyses, form cross-fertilization, and engage with other professionals - including urban planners, policy-makers and development workers - in order to deepen our understanding of what sustainable and inclusive urban development actually means. The conceptualization of 'urban land grabs' provides a framework to interpret ongoing experiences. More specifically, we propose three concrete topics for further research and collaboration.

First, it is important to recognize that even when investments are in the planning stage, they trigger dynamics that cannot be ignored. For example, delays in the development of envisioned first-class urban areas in the peri-urban fringes of Khartoum result in a continuous flow of land transactions between locals and transnational migrants (Kaag and Steel, this issue). This has triggered illegal sand extraction, making the planned area less suitable for the intended residential development. Such unplanned consequences in turn affect the investment projects as much as the local living conditions. Yet, as discussions on 'world city making' (Roy and Ong, 2011) have shown, image building and city branding create expectations of a promising urban future, and this is key to making people believe in increased land values and convincing them to invest in land, irrespective of the question of whether real profits will be realized (van Noorloos et al., 2018). This is how new master plans are continually proposed, leading to new commodification and speculation (Shannon, this issue; van Noorloos, Avianto and Opiyo, this issue; Fält, this issue). We need to monitor closely what effects are generated when these master plans and other urban developments are announced, long before they materialize.

Second, many of the current investment projects seem exclusionary. As Watson (2013, p. 15) indicates, 'a widening and deepening of inequality is inevitable' when various competing claims to land heighten the pressure on that land. This is primarily because investment projects often target well-located land, leading to demolition of informal settlements and displacing a large number of urban poor. As Otsuki (this issue) has shown, displacement happens when people are considered to be 'in the way' of someone else's (usually more privileged people's) future 'development'. Even when a relatively 'inclusive' international donor is involved, the retroliberal policies have resulted in dispossession of the poor from their land and livelihoods as 
in Beira, Mozambique (Shannon, this issue), leaving many marks of speculative urbanism in African cities (Goldman 2011). As many African cities are facing such displacement and dispossession of the poor, it is of vital importance to look into the long-term processes of how these exclusionary processes are experienced on the ground on the fringes of investments (van Noorloos, Avianto and Opiyo, this issue).

Last but not least, we must not lose sight of the human agency of urban dwellers in African cities. While we tend to pay attention to large scale, governmental and masterplanned projects that are of an exclusionary nature, poor and marginalized people continually invest in their own development. This is clearly visible in informal settlements where people 'grab' their own land to demonstrate their social and moral obligation, as shown in Stacey's article (this issue). They are not only being dispossessed but have the potential to repossess their land and opportunity by investing in or negotiating infrastructure for their own development (Otsuki, this issue). We need to pay closer attention to their strategies and plans for the future of urban settlements, which develop in relation to, but often independently from, the official regulatory and planned framework. In this sense, the role of the diaspora (Kaag and Steel, this issue) and traditional authority (Fält, this issue) are also important since they show us the workings of alternative power dynamics in African cities.

We hope that this special issue opens the door to further exploration of these topics and others. At least, we wish to bring more recognition of the dynamics of investment that take place in African cities as central to understanding and countering exclusionary urban development.

\section{REFERENCES}

Berrisford, S., Cirolia, L.R. and Palmer, I. (2018) Land based financing in sub-Saharan African cities. Environment and Urbanization, 30(1), pp. 35-52.

Bhan, G. (2014) The real lives of urban fantasies. Environment and Urbanization, 26(1), pp. 232235.

Blanco, A., Fretes Cibils, V. and Muñoz, A. (2016) Expandiendo el uso de la valorización del suelo: La captura de plusvalías en América Latina y el Caribe. Washington, DC: Inter-American Development Bank.

Brenner, N. (ed.) (2014) Implosions/Explosions: Towards a Study of Planetary Urbanization. Berlin: JOVIS Verlag.

Bon, B. (2015) A new megaproject model and a new funding model. Travelling concepts and local adaptations around the Delhi metro. Habitat International, 45, pp. 223-230.

Borras, S. and Franco, J.C. (2013) Global land grabbing and political reactions 'from below'. Third World Quarterly, 34(9), pp. 1723-1747.

Côté-Roy, L. and Moser, S. (2018) ‘Does Africa not deserve shiny new cities?' The power of seductive rhetoric around new cities in Africa. Urban Studies, e-pub ahead of print, https://doi.org/10.1177/ 0042098018793032.

Cotula, L., Vermeulen, S., Leonard, R. and Keeley, J. (2009) Land Grab or Development Opportunity? Agricultural Investment and International Land Deals in Africa. London/Rome: IIED, FAO, IFAD.

De Boeck, F. (2014) Challenges of urban growth. Towards an anthropology of urban infrastructure in Africa, in Lepik, A. (ed.) Afritecture. Building Social Change. Ostfildern: Hatje Cantz Verlag, pp. 92-102.

Deininger, K. and Byerlee, D. (2011) Rising Global Interest in Farmland. Can it yield Equitable and Sustainable Benefits? Washington DC: World Bank.

Fält, L. (2016) From shacks to skyscrapers: multiple spatial rationalities and urban transformation in Accra, Ghana. Urban Forum. https://link. springer.com/article/10.1007/s12132-016-9294-8.

Grant, R. (2015) Sustainable African urban futures. Stocktaking and critical reflection on proposed urban projects. American Behavioral Scientist, 59(3), pp. 294-310.

Goldman, M. (2011) Speculative urbanism and the making of the next world city. International Journal of Urban and Regional Research, 35(3), pp. 555-581.

Holmes, G. (2014) What is a land grab? Exploring green grabs, conservation, and private protected areas in southern Chile. Journal of Peasant Studies, 41(4), pp. 547-567. 
Kaag, M. and Zoomers, A. (eds.) (2014) The Global Land Grab. Beyond the Hype. London: Zed Books.

Leitner, H. and Sheppard, E. (2016) Provincializing critical urban theory: extending the ecosystem of possibilities. International Journal of Urban and Regional Research, 40(1), pp. 228-235.

Mbiba, B. (2017) Idioms of accumulation: corporate accumulation by dispossession in urban Zimbabwe. International Journal of Urban and Regional Research, 41(2), pp. 213-234.

Murray, M.J. (2015a) 'City doubles': re-urbanism in Africa, in Miraftab, F., Wilson, D. and Salo, K. (eds.) Cities and Inequalities in a Global and Neoliberal World. New York: Routledge, pp. 92109.

Murray, M.J. (2015b) Waterfall City (Johannesburg): privatized urbanism in extremis. Environment $\mathcal{E}$ Planning A, 47(3), pp. 503-520.

Myers, G. (2015) A world-class city region? Envisioning the Nairobi of 2013. American Behavioral Scientist, 59(3), pp. 328-346.

Otsuki, K, Schoneveld, G. and Zoomers, A. (2017) From land grabs to inclusive development? Geoforum, 83, pp. 115-118.

Parnell, S. (2016) Defining a global urban development agenda. World Development, 78, pp. 529540.

Parnell, S. and Pieterse, E. (eds.) (2014) Africa's Urban Revolution. London: Zed Books.

Parnell, S. and Pieterse, E. (2015) Translational global praxis: rethinking methods and modes of African urban research. International Journal of Urban and Regional Research, 40(1), pp. 237-246.

Parnell, S. and Robinson, J. (2012) (Re)theorizing cities from the global South: looking beyond neoliberalism. Urban Geography, 33(4), pp. 593617.

Robinson, J. and Roy, A. (2016) Debate on global urbanisms and the nature of urban theory. International Journal of Urban and Regional Research, 40(1), pp. 181-186.

Potts, D. (2012) Challenging the myths of urban dynamics in Sub-Saharan Africa: the evidence from Nigeria. World Development, 40(7), pp. 1382-1393.

Roy, A. and Ong, A. (eds.) (2011) Worlding Cities: Asian Experiments and the Art of Being Global. Oxford: Wiley-Blackwell.

Scott, A.J. and Storper, M. (2015). The nature of cities: the scope and limits of urban theory. International Journal of Urban and Regional Research, 39(1), pp. 1-15.
Sheppard, E., Gidwani, V., Goldman, M., Leitner, H., Roy, A. and Maringanti, A. (2015) Introduction: urban revolutions in the age of global urbanism. Urban Studies, 52(11), pp. 1947-1961.

Shin, H.B. and Kim, S. (2016) The developmental state, speculative urbanisation and the politics of displacement in gentrifying Seoul. Urban Studies, 53(3), pp. 540-559.

Shin, H.B., Lees, L. and López-Morales, E. (2016) Introduction: locating gentrification in the global east. Urban Studies, 53(3), pp. 455-470.

Steel, G., van Noorloos, F. and Klaufus, C. (2017) The urban land debate in the global South: new avenues for research. Geoforum, 83, pp. 133-141.

UN-Habitat (2016) World Cities report 2016: Urbanization and Development: Emerging Futures. Nairobi: UN-Habitat.

Van Noorloos, F., Klaufus, C. and Steel, G. (2018) Land in urban debates: unpacking the grabdevelopment dichotomy. Urban Studies. https:// doi.org/10.1177/0042098018789019.

Van Noorloos, F. and Kloosterboer, M. (2018) Africa's new cities: the contested future of urbanisation. Urban Studies, 55(6), pp. 12231241.

Watson, V. (2009) Seeing from the South: refocusing urban planning on the globe's central urban issues. Urban Studies, 46(11), pp. 2259-2275.

Watson, V. (2013) African urban fantasies: dreams or nightmares? Environment and Urbanization, 26(1), pp. 215-231.

Wolford, W., Borras, S.M., Hall, R., Scoones, I. and White, B. (2013) Governing global land deals: the role of the state in the rush for land. Development and Change, 44, pp. 189-210.

Zoomers, A. (2010) Globalisation and the foreignisation of space: seven processes driving the current global land grab. Journal of Peasant Studies, 37(2), pp. 429-447.

Zoomers, A. and Otsuki, K. (2017) Addressing the impacts of large-scale land investments: reengaging with livelihood research. Geoforum, 83, pp. 164-171.

Zoomers, A., van Noorloos, F., Otsuki, K., Steel, G. and van Westen, G. (2017) The rush for land in an urbanizing world: from land grabbing toward developing safe, resilient, and sustainable cities and landscapes. World Development, 92, pp. 242-252. 